\title{
Decoding Gene Patents in Australia
}

\author{
Adam Denley and James Cherry \\ Freehills Patent Attorneys, Melbourne, Victoria 3000, Australia \\ Correspondence: james.cherry@freehillspatents.com
}

Patents directed to naturally occurring genetic material, such as DNA, RNA, chromosomes, and genes, in an isolated or purified form have been granted in Australia for many years. This review provides scientists with a summary of the gene patent debate from an Australian perspective and specifically reviews how the various levels of the legal system as they apply to patents - the Australian Patent Office, Australian courts, and Australian government-have dealt with the issue of whether genetic material is proper subject matter for a patent.

\begin{abstract}
ustralia has long fostered an environment Athat encourages both basic and applied scientific research that has led to the development of a research community that consistently ranks high against a range of international benchmarks for productivity and quality. ${ }^{1}$ In line with this, Australia has a patent system that provides a framework for securing rights in inventions arising from scientific research.

Australia has a long history of taking a generous view to the types of things that can be patented. Both the Australian Patent Office (APO) and Australian courts have acknowledged that excluding certain types of inventions from the patent system may stifle the incentive that patents provide for research, development,

\footnotetext{
${ }^{1}$ For example, as measured by research output (journal publications and citations) over the decade from 2001 to 2010, Australia ranked sixth internationally in terms of citations per publication. And over all disciplines, Australia has produced 15 Nobel laureates, the highest number per head of population of any country. Strategic Review of Health and Medical Research, Final Report, February 2013, 1.4.2.
}

and commercialization of technology. Consequently, patents for advances in life sciences research have been sought and regularly granted in Australia. In this environment, certain special interest groups and members of the Australian public have sought to call into question the patentability of various types of genetic material. This has seen the completion of a number of parliamentary reviews and a high-profile court case that is still alive today.

In this review, we consider the following: what is patentable in Australia; how patents directed to genetic material have been considered by the APO; the Myriad court case in Australia; previous proposals for legislative change to restrict patenting on genetic material; and recent changes to the Australian patents legislation.

\section{WHAT CAN BE PATENTED IN AUSTRALIA?}

For those not familiar with patents and processes for obtaining them, we now briefly outline the key concepts. A patent is a legally enforce-

Editors: Salim Mamajiwalla and Rochelle Seide

Additional Perspectives on Intellectual Property in Molecular Medicine available at www.perspectivesinmedicine.org

Copyright (C) 2015 Cold Spring Harbor Laboratory Press; all rights reserved; doi: 10.1101/cshperspect.a020909

Cite this article as Cold Spring Harb Perspect Med 2015;5:a020909 
able right to exclude others from doing certain things such as making, using, and selling a patented invention for a limited time. Patent rights are national rights, and therefore, before a patent is granted conferring rights to the patented invention, a patent office, acting on behalf of the government, examines the patent application to determine if the invention it describes meets a number of criteria-for example, being new, inventive, and useful. Once the patent office considers that those criteria are met, a patent will be granted. The extent of protection conferred by a patent is defined by the claims contained in the patent specification.

One requirement for a patent to be granted in Australia is that it must claim an invention that is a "manner of manufacture" - that is, the Australian equivalent of "patentable subject matter" in the United States. This is a term of law that essentially means that what is being sought to be patented is the correct subject matter of a patent. This is an eligibility criterion that is easily understood by analogy to obtaining a driver's license. To obtain a driver's license one must pass a driving test, but before that test can be taken, an eligibility criterion of an age limit must be met. In a similar way, there are various tests a patent application must meet before it is granted. However, these tests are not relevant unless the invention described in the patent application meets the eligibility criteria of a "manner of manufacture."

The core tenet of the patent system is to reward an inventor for his or her endeavors by conferring, for a limited time, the right to prevent others from doing what the patent claims. However, anything and everything cannot be the subject of a patent. In Australia, there are express exclusions of certain types of things from patentable subject matter, and these include human beings and the biological processes for their generation. ${ }^{2}$ For a second-tier system of patents, called innovation patents, plants and animals and the biological processes for their generation are also excluded from patentability. ${ }^{3}$

${ }^{2}$ Patents Act 1990 s 18(2).

${ }^{3}$ Patents Act 1990 s 18(3).
There is no express exclusion of genetic material from patentable subject matter, although there have been various attempts to change the Australian Patents Act to exclude biological materials, and this is discussed later in this review.

The APO has a long history of granting patents to a broad range of inventions that arise from life sciences research. IP Australia also explains on its website that the following types of subject matter can be pursued in a standard patent: ${ }^{4}$

A standard patent can be obtained for isolated bacteria, cell lines, hybridomas, related biological materials and their use, and genetically manipulated organisms. Examples of patentable inventions include:

- isolated bacteria and other prokaryotes, fungi (including yeast), algae, protozoa, plasmids, viruses, prions

- cell lines, cell organelles, hybridomas

- genetic vectors and expression systems

- apparatus or processes for enzymology or microbiology

- compositions of micro-organisms or enzymes

- propagating, preserving or maintaining micro-organisms

- mutagenesis or genetic engineering

- fermentation or enzyme using processes to synthesise a desired compound or composition

- measuring or testing processes involving enzymes or micro-organisms

- processes using enzymes or micro-organisms to liberate, separate, purify or clean

- the use of micro-organisms to produce food or beverages

The patentability of microorganisms in Australia has been considered, ${ }^{5}$ and the following principles can be derived.

${ }^{4}$ IP Australia, Patents for Biological Inventions, www .ipaustralia.gov.au/get-the-right-ip/patents/about-patents/ what-can-be-patented/patents-for-biological-inventions/ as at November 22, 2013.

${ }^{5}$ Ranks Hovis McDougall Ltd's Application (1976) 46 AOJP 3915. 
- No objection can be taken to a claim to a new organism on the ground that it is something living.

- Any new variants claimed must have improved or altered useful properties and not merely have changed morphological characteristics which have no effect on the working of the organism.

- Naturally occurring micro-organisms per se are not patentable as they represent a discovery and not an invention.

- A claim to a pure culture of the micro-organism would satisfy the requirements for technical intervention where previously only known to exist in heterogeneous culture.

\section{CONSIDERATION OF PATENTS ON GENETIC MATERIAL BY THE APO}

The APO has regularly granted patents with claims defining gene sequences. However, the first express comment from a senior official on whether gene sequences are patentable subject matter arose during a dispute over a patent claiming erythropoietin sequences (Kirin-Amgen Inc v. Board of Regents of University of Washington and Genetics Institute, Inc. (1995) (33 IPR 557)). Although the central issues in that dispute were directed to other grounds of patentability, the official chose to comment on whether a claim to a DNA sequence that encodes a human protein was appropriate subject matter for a patent or was simply a mere discovery. The patent claims in question were directed to DNA sequences encoding, among other things, wild-type and mutated human and monkey erythropoietin. The claims directed to wildtype human and monkey erythropoietin were considered by the Patent Office to define subject matter that was appropriate for patenting as they defined the DNA sequences as being "purified and isolated." The claims directed to mutated human and monkey erythropoietin were considered patentable as they defined DNA sequences that had been deliberately changed from the naturally occurring form. By claiming an isolated and purified, or mutated, DNA se- quence, the claims were considered to be for more than just a discovery per se. The parties in the dispute before the APO took the matter to the Federal Court of Australia; however, whether claims to DNA sequences were directed to patent-eligible subject matter was not considered (Genetics Institute, Inc v. Kirin-Amgen, Inc. (1996) (34 IPR 513)).

The construction of terms such as "isolated," "purified," and "recombinant" has been considered by the APO to distinguish a claimed DNA sequence from the naturally occurring DNA. ${ }^{6}$ The Patent Manual of Practice \& Procedure, which provides direction to examiners on how to examine patent applications, states:

Thus, a micro-organism, protein, enantiomer or antibiotic discovered in nature can be claimed in its isolated form, or as substantially free of (specified) impurities. Similarly, a gene can be claimed in its recombinant or isolated or purified form [see Ranks Hovis McDougall Ltd's Application (1976) (AOJP 3915)]. ${ }^{7}$

To provide further guidance to examiners on what genetic material is patentable subject matter, the APO has published the following guidelines on its website: ${ }^{8}$

A standard patent can also be obtained for inventions involving:

- genotypically or phenotypically modified living organisms, for example, genetically modified bacteria, plants and non-human organisms ( patenting of plant varieties is described in Plant Breeder's Rights)

- isolated DNA, RNA, chromosomes and genes (including human DNA and genes)

- isolated products of such DNA, RNA and genes including polypeptides and proteins

Examples of patentable inventions include:

- synthetic genes or DNA sequences

${ }^{6} D S M N V v$ Novo Nordisk A/S (g210) APO 33 (19 July 2001): “. . once it is purified and isolated this would distinguish it from the naturally occurring DNA."

${ }^{7}$ IP Australia, Patent Manual of Practice \& Procedure, National (2013), [2.9.2.5].

${ }^{8} \mathrm{IP}$ Australia, Patents for Genetic Modification and Manipulation, www.ipaustralia.gov.au/get-the-right-ip/patents/ about-patents/what-can-be-patented/patents-for-biologicalinventions/ as at November 22, 2013. 
- mutant forms and fragments of gene sequences

- an isolated DNA coding sequence for a gene

- an isolated protein expressed by a gene

- vectors (such as plasmids or bacteriophage vectors or viruses) containing a transgene

- methods of transformation using a gene

- host cells carrying a transgene

- higher plants or animals carrying a transgene

- organisms for expression of a protein from a transgene

- general recombinant DNA methods such as PCR and expression systems

\section{PATENT ACTIVITY IN AUSTRALIA FOR GENETIC MATERIAL}

Due to the varying language used in patent claims, it is difficult to estimate the total number of patents or pending patent applications that are directed to isolated human genes. An Australian senator in 1997 asked the APO how many patent applications had been filed in Australia for genes or gene sequences and how many of those had proceeded to grant. The APO estimated that a total of $\sim 8100$ patent applications concerning genes or gene sequences had been filed. ${ }^{9}$ As of 1997, the APO estimated that this figure equated to $\sim 1.8 \%$ of all patent applications filed in Australia since 1975. However, the APO estimated that about one-quarter (2100) of those patents had been granted.

A more recent investigation based on different searching strategies, however, estimated that the total number of patents and patent applications ever filed in Australia that claim a fulllength or partial isolated human gene sequence is between 3000 and $4400 .^{10}$ This number is very small compared to the $\sim 12,000$ patents estimated to have been granted in the United States that claim human gene sequences. ${ }^{11}$

\footnotetext{
${ }^{9}$ Hansard Reports: Questions on Notice: Gene Sequences Patents: Monday, 24 March 1997, Senator Parer.

${ }^{10}$ Economic Analysis of the Impact of Isolated Human Gene Patents, Centre for International Economics Final Report, May 2013, www.ipaustralia.gov.au/pdfs/IPA-Final-Report_ Human-Gene-Patents-2013.pdf.

${ }^{11}$ From Graff GD, Phillips D, Lei Z, Oh S, Nottenburg C, Pardey PG. 2013. Not quite a myriad of gene patents. Nat Biotechnol 31: 404-410.
}

It should be noted that the number of patent applications that contain claims that are directed to nucleic acids having a sequence of a human gene has been decreasing since the publication of the nucleotide sequences by Celera and the Human Genome Project. ${ }^{12}$ It appears that since publication of the updated draft sequences and corresponding analysis in 2003, the focus of patents has shifted to methods of using isolated genetic material or to genetic material that does not have a naturally occurring counterpart, that is, contains nonnative mutations or synthetic nucleotides. To emphasize the significance of the Celera/Human Genome Project publications on the types of patent claims in Australia, it has been reported that no patents filed after 2003 contain claims to a full-length gene sequence encoding a human protein. $^{13}$

\section{THE GENE PATENT DEBATE IN AUSTRALIA}

As in most countries, the Australian debate on the patenting of genetic material, or as more commonly quoted in the media, "gene patents," has not been confined to the courts and the realms of academia. Instead, mainstream Australian media has been printing articles and opinion pieces on whether or not gene patents should be granted in Australia. Several sensational headlines have been found in various newspapers, including "Claim for gene an affront to nature,"14 "Genetic inheritance belongs to all humanity," and "It's patently unfair Biotech firms hold patients to ransom over vital

\footnotetext{
${ }^{12}$ Economic Analysis of the Impact of Isolated Human Gene Patents, Centre for International Economics Final Report, May 2013.

${ }^{13}$ Economic Analysis of the Impact of Isolated Human Gene Patents, Centre for International Economics Final Report, May 2013, p. 75. However, this conclusion was based on a randomized sampling of a data set obtained by searching the Australian Patent Office database AusPat. The search strategy and limitations are discussed at 3.1 and in Appendix A. 14"Claim for gene an affront to nature," Jane Fynes-Clintion, Courier Mail (Australia), February 23, 2012.

15 "Genetic inheritance belongs to all humanity," The Age (Australia), February 22, 2012.
} 
tests, research."16 The debate in Australia has led to three federal government inquiries ${ }^{17}$ and multiple attempts by politicians to change the legislation to exclude certain biological material from patentability. The public debate on whether or not patents claiming gene sequences are allowable and the actions of certain owners of patents on genetic material have resulted in a court case in which the validity of patents directed to gene sequences that correspond to wild-type, mutant, and polymorphic BRCA1 and BRCA2 was challenged. This court case, commonly referred to as the "Myriad case," is the first judicial consideration in Australia on whether a valid patent may be granted for a claim that covers naturally occurring nucleic acid-either DNA or RNA - that has been "isolated" (Cancer Voices Australia v. Myriad Genetics Inc. (2013) (FCA 65) (1)).

\section{BACKGROUND TO THE MYRIAD CASE IN AUSTRALIA}

Genetic Technologies Limited (GTG) is the exclusive licensee in Australia of the Myriad Genetics patents that are directed to the BRCA1 and BRCA2 nucleic acids and their uses in diagnosing breast cancer risk. In settling a previous infringement suit, Myriad received a nonexclusive license to GTG's patent over noncoding DNA so that it could continue BRCA testing in other jurisdictions. In Australia, GTG initially permitted various hospitals and clinics to take nonexclusive licenses for BRCA testing, but in July 2008, it announced that it would

\footnotetext{
16“'It's patently unfair Biotech firms hold patients to ransom over vital tests, research," Tory Shepherd, Advertiser (Australia), June 9, 2010.

${ }^{17}$ 1. Australian Law Reform Commission, Genes and Ingenuity: Gene Patenting and Human Health (ALRC Report 99, August 30, 2004), www.alrc.gov.au/publications/report-99. 2. Australian Senate Community Affairs Committee Inquiry into Gene Patents, Final Report, November 24, 2010, www .aph.gov.au/Parliamentary_Business/Committees/Senate/ Community_Affairs/Completed_inquiries/2008-10/gene_ patents/index. 3. Advisory Council on Intellectual Property, Review of Patentable Subject Matter, Final Report, February 16, 2011, www.acip.gov.au/reviews/all-reviews/reviewpatentable-subject-matter/.
}

reverse its position and begin enforcing the licensed Myriad patents. Although GTG ultimately reverted to its original position of providing nonexclusive licenses to organizations for BRCA testing, the public storm that arose led to an Australian Senate inquiry. On November 11, 2008, the Senate referred matters relating to the patenting of human genes and genetic materials to the Senate Community Affairs References Committee for inquiry and report. GTG's threat to enforce its licensed patents likely sowed the seeds for the current litigation considered in the next section of this article.

\section{MYRIAD LITIGATION IN AUSTRALIA}

In a landmark decision regarding the patentability of genetic material, the Federal Court of Australia has held that any nucleic acid found in cells, whether it be DNA or RNA, that has been removed from the cellular environment in which it naturally exists is patentable (Cancer Voices Australia v. Myriad Genetics Inc. (2013) (FCA 65)). The court held that "isolated nucleic acid is the product of human intervention ..." involving the extraction and purification of nucleic acids found in the cell. The court reasoned that in the absence of human intervention, naturally occurring nucleic acids do not exist outside the cell and "isolated nucleic acids" do not exist inside a cell (Cancer Voices Australia v. Myriad Genetics Inc. (2013) (FCA 65) (108)).

This decision will be welcomed by the biotechnology community, which relies heavily on patents to underpin its business. Moreover, this decision extends beyond genetic material with a human origin to molecules from animals, plants, and microorganisms.

Despite the significant attention that this case has received, the judgment itself will not change the current landscape for patent applicants or patentees in relation to what is patentable subject matter. Perhaps of more importance to applicants will be the legislative changes that will serve to increase standards of other requirements for patentability, as discussed at the end of this article. 
The only claims at issue in the Myriad case were the following.

1. An isolated nucleic acid coding for a mutant or polymorphic BRCA1 polypeptide, said nucleic acid containing in comparison to the BRCA1 polypeptide encoding sequence set forth in SEQ.ID No:1 one or more mutations or polymorphisms selected from the mutations set forth in Tables 12, 12A and 14 and the polymorphisms set forth in Tables 18 and 19.

2. An isolated nucleic acid as claimed in claim 1 which is a DNA coding for a mutant BRCA1 polypeptide, said DNA containing in comparison to the BRCA1 polypeptide encoding sequence set forth in SEQ.ID No:1 one or more mutations set forth in Tables 12, 12A and 14.

3. An isolated nucleic acid as claimed in claim 1 which is a DNA coding for a polymorphic BRCA1 polypeptide, said DNA containing in comparison to the BRCA1 polypeptide encoding sequence set forth in SEQ.ID No:1 one or more polymorphisms set forth in Tables 18 and $19 .^{18}$

Claim 1 includes isolated DNA, RNA, and complementary DNA (cDNA) that code for a BRCA1 polypeptide sequence as shown in SEQ ID No. 1, with one or more of the mutations or polymorphisms specified in tables that list various polymorphisms in BRCA1 genomic DNA exons. In contrast, claims 2 and 3 extend only to DNA containing one or more of the identified mutations or polymorphisms.

Although there were 27 other claims, including methods for diagnosing a predisposition for breast and ovarian cancer in a human subject, only the three claims listed above were challenged. By challenging only these claims and only on a single ground of attack, this litigation was essentially a test case for whether the mere fact of isolating genetic material from its native environment was sufficient to make it patentable.

${ }^{18}$ Australian Patent No. 686004.

\section{THE ISSUE: IS ISOLATED GENETIC MATERIAL A "MANNER OF MANUFACTURE"?}

The only issue in this case was whether a naturally occurring nucleic acid that has been isolated is patentable subject matter (i.e., a manner of manufacture) in Australia.

The starting point for considering whether claimed subject matter is a manner of manufacture was the decision by the High Court of Australia in National Research Development Corporation v. Commissioner of Patents (1959) (102 CLR 252). The principles in that decision can be distilled into two questions, which if both are answered in the affirmative indicate that the subject matter is patentable.

1. Does the subject matter of the claim consist of an artificially created state of affairs?

2. Does the subject matter of the claim provide a new and useful effect that is of economic significance?

The second question was acknowledged by both parties to be answered in the affirmative. Therefore, the sole issue to be considered was whether the claimed naturally occurring, "isolated" nucleic acids consisted of an artificially created state of affairs. For there to be an artificially created state of affairs in relation to a composition of matter, the judge noted that there must be some human intervention, although it is difficult to quantitate what level of human intervention is required (Cancer Voices Australia v. Myriad Genetics Inc. (2013) (FCA 65) (102)).

In the context of biological material, the court was of the view that an artificially created state of affairs may arise if the physical properties of the naturally occurring material have changed as a result of isolation. To this effect, the court construed "isolated" to imply that naturally occurring nucleic acid found in the cells of the human body, whether DNA or RNA, had been removed from the cellular environment in which it naturally existed and separated from other cellular components. Even if the claimed nucleic acid had precisely the same chemical composition and structure as that found in a cell, the court concluded that the nucleic acid is patentable subject matter on 
the basis that it has been extracted from cells and purged of other biological materials with which it was associated in the cell.

In reaching the conclusion that an isolated nucleic acid constitutes an artificially created state of affairs, the court reasoned as follows.

- The High Court in NRDC took a broad view as to the concept of "manner of manufacture."

- Isolation of a nucleic acid involves human intervention (i.e., extraction)—rupturing the cell membrane and physical destruction of the cell-and purification-removal of other materials originally present in the cell.

- There should be reward for effort and skill for the development of the invention.

The court also noted that the decision in NRDC does not require one to ask whether a composition of matter is a "product of nature" or whether it is "markedly different" from something that exists in nature.

The court considered the legal positions in the United Kingdom ${ }^{19}$ and the United States (The Association for Molecular Pathology \& Ors v. United States Patent and Trademark Office and Myriad Genetics Inc. (689 F. 3d 1303) (2012)) in relation to the patentability of isolated DNA or RNA but did not appear to be influenced by the stance taken in those jurisdictions.

The position taken by this Australian court is in contrast to that of the U.S. Supreme Court, which, when dealing with the Myriad litigation in the United States, held that "A naturally occurring DNA segment is a product of nature and not patent eligible merely because it has been isolated ..." (Association for Molecular Pathologyv. Myriad Genetics (569 U.S. 12-398) (2013)).

The Myriad decision was appealed to the Full Court of the Federal Court of Australia (Yvonne D'Arcy v. Myriad Genetics Inc. \& Anor (NSD 359/2013)). The Notice of Appeal contended that, among other things, the judge erred in holding that the fact of human intervention, per se, in the process of isolation was

${ }^{19}$ Patents Act (UK) 1977, s76A and Schedule A2. relevant to the question of whether the claimed isolated nucleic acid constituted patentable subject matter.

In early September 2014, the Full Federal Court (five judges) unanimously dismissed the appeal and affirmed that isolated nucleic acids (i.e., whether it be DNA or RNA) are patentable subject matter in Australia (D'Arcy v. Myriad Genetics Inc [2014] FCAFC 115). Although an appeal to the High Court of Australia is possible, absent an appeal, isolated nucleic acids will remain patentable subject matter under Australian patent law, particularly if different in any way from the structure of its natural counterpart.

Consistent with previous principles derived from Australian case law, the Full Federal Court held that the claimed isolated nucleic acid, including cDNA, resulted in an artificially created state of affairs for economic benefit, thereby being proper subject matter of a patent. By being removed from the genome and the cell (in other words, removed from the natural environment and from the cellular components that enable it to function in vivo), the Court held that the claimed isolated nucleic acid is itself an artificially created state of affairs.

\section{CONSEQUENCES FOR INFRINGEMENT OF THE TERM “ISOLATED"}

An interesting question that now arises from this decision is to what extent a nucleic acid has to be "isolated" in order to infringe a claim in this form.

A U.K. court (Monsanto Technology v. Cargill International (2007) (EWHC 2257) (Pat)) narrowly construed "isolated" in the context of a claim to an isolated DNA sequence as meaning separated from other molecular species in the form of a purified DNA fragment. In that case, a soybean meal containing the claimed DNA sequence was not found to be an infringement as the DNA sequence in the soybean meal was not purified and, therefore, was not isolated.

Although this decision is not law in Australia, it highlights the need to carefully draft claims to nucleic acids, or at least provide care- 
fully worded dictionary-style definitions in the description, to balance the need to meet the "manner of manufacture" requirement while not inviting the court to adopt an unduly narrow construction. In this case, applicants should also consider including claims to nucleic acids in a composition that represent the commercial product or an intermediate product in the production process.

\section{BUSINESS AS USUAL?}

The decision in the Myriad case does not change the law as it has been applied by the APO for more than 30 years. The APO should continue to allow patent applicants to claim genetic material, provided the claimed material is qualified as having been "isolated," or words to that effect.

In one sense, this decision is reassuring for both present and future patent applicants in that the status quo in Australia has not changed. However, it must be acknowledged that this decision only deals with one requirement that an invention must meet to be a patentable invention. The mere isolation of a nucleic acid, while likely to be patentable subject matter, is unlikely to meet the other requirements for a patentable invention, for example, utility, inventive step, etc. Even before this decision, it was difficult to secure a claim to an isolated nucleic acid without attributing some sort of function or additional feature to the nucleic acid so as to overcome the inventive-step hurdle. Furthermore, as outlined earlier in this article, the rapid expansion of the prior art base of genetic sequences through publication of the Human Genome Project and second-generation sequencing has made obtaining claims to isolated, naturally occurring DNA or RNA very difficult.

\section{PROPOSALS FOR LEGISLATIVE CHANGE}

In November 2010, four Australian senators introduced a bill ${ }^{20}$ into the Australian parliament proposing to replace the current provisions that

${ }^{20}$ Patent Amendment (Human Genes and Biological Materials) Bill 2010. expressly exclude certain things from patentable subject matter. The impact of the bill is to expand from just human beings and biological processes for their generation to "biological materials including their components, whether isolated or purified or not and however made, which are identical or substantially identical to such materials as they exist in nature." For the purposes of the proposed provision, "biological materials" was stated to include DNA, RNA, proteins, cells, and fluids.

The Australian senators stated that the purpose of the bill was "to advance medical and scientific research and the diagnosis, treatment and cure of human illness and disease by enabling doctors, clinicians, medical and scientific researchers to gain free and unfettered access to biological materials, however made, that are identical or substantially identical to such materials as they exist in nature." ${ }^{21}$

This bill was referred by the Australian parliament to a Senate committee for review. The Senate committee made a single recommendation: "The committee recommends that the Senate should not pass the Bill." ${ }^{22}$

This recommendation was not surprising given the expansive form of the proposed exclusion. If the bill were to be made law, it is likely that almost any biological material made in a laboratory would be unpatentable. As an example, consider a scenario in which an antibody has been identified from a phage display library and affinity-matured against a target antigen by several rounds of selection. The antibody that exhibits the desired characteristics may have variable region sequences that are not found in any antibody identified previously in nature, but it would not be patentable given the proposed provisions if it was similar, in other words, substantially identical, to a previously known naturally occurring antibody. Furthermore, given the almost unlimited possibility of

\footnotetext{
${ }^{21}$ Explanatory memorandum for Patent Amendment ( $\mathrm{Hu}-$ man Genes and Biological Materials) Bill 2010.

${ }^{22}$ The Australian Senate Legal and Constitutional Affairs Legislation Committee, Patent Amendment (Human Genes and Biological Materials) Bill 2010.
} 
antibody sequences due to somatic hypermutation and $V(D) J$ recombination, any antibody ever produced in the laboratory could arguably be substantially identical to a naturally occurring antibody and, therefore, be unpatentable under this provision.

Although the committee recommended that the bill should not pass the Senate with the wording of the provisions as outlined above, it did recommend that the Senate should pass the bill if the exclusion of patentable subject matter was limited to "biological materials, whether isolated or not and however made, which are identical to such materials as they exist in nature." The committee proposed a definition of "biological materials" to include DNA, RNA, proteins, cell fluids, and their components and a definition of "identical" as meaning biological material that is structurally and functionally identical. ${ }^{23}$ An amended bill was never entered into parliament.

It is likely that there will be further attempts to change the current Australian Patents Act to exclude various biological materials; however, at the present time, the status quo remains.

This has not been the first time that there has been a push from politicians to amend the Patents Act to exclude various genetic material from patentable subject matter. In the parliamentary debate in 1990 that led to the enactment of the current patents act, Patents Act 1990, there was a significant push from certain senators to exclude genes and related genetic material from patentable subject matter. This was due to a concern that without a specific exclusion, the human genome could be patented. A senator at the time stated:

Obtaining the human genome blueprint is the ultimate answer to the commandment 'Know Thyself.' It is the Holy Grail of biology. What this legislation is about-unless amendedwould allow the Holy Grail to be patented. ${ }^{24}$

\footnotetext{
${ }^{23}$ The Australian Senate Legal and Constitutional Affairs Legislation Committee, Patent Amendment (Human Genes and Biological Materials) Bill 2010, p. 101.

${ }^{24}$ Hansard Reports: Senate-Patents Bill 1990-Monday, 17 September 1990, Senator Coulter quoting Walter Gilbert, Harvard biologist, in the first sentence quoted above.
}

The amendments proposed in 1990 excluded the following: (1) gene or genes, whether derived from cells or chemically synthesized; (2) a genome either complete or one that has had genetic material added or deleted; (3) the altered organism (human, plant, animal, or microorganism) produced by having its genome manipulated; and (4) the progeny of the genetically engineered organism that also carries the altered genome. These proposed exclusions were ultimately opposed by the government at the time and the opposition. ${ }^{25}$

\section{AMENDMENTS TO THE PATENTS ACT}

The Patents Act 1990 was amended in April 2013, leading to new patentability standards that came into force in Australia by way of the "Raising the Bar" Act. ${ }^{26}$ As a result of these changes to Australian patent law, a new utility standard will be applied to certain applications after April 15, 2013, potentially making it more difficult to claim isolated, naturally occurring DNA or RNA than in the past. Also, the new law expands the prior art base and the common general knowledge relevant to testing inventive step.

The "manner of manufacture" requirement, however, has not been changed, and despite public pressure, the "Raising the Bar" Act did not introduce any limitations as to what constitutes patentable subject matter. It has, however, introduced an experimental use exemption, whereby a person will not be deemed to be infringing a patent by doing an act for the predominant purpose of gaining new knowledge or to test a principle or supposition regarding the patented invention. Although it will be some time before we have any guidance from the courts as to what constitutes experimental use, the provision will hopefully provide some comfort to those concerned by the outcome of the Myriad case as allegedly stifling experimental research.

\footnotetext{
${ }^{25}$ Hansard Reports: Senate-Patents Bill 1990-Monday, 17 September 1990, Senator Collins.

${ }^{26}$ Intellectual Property Laws Amendment (Raising the Bar) Act 2012.
} 
A. Denley and J. Cherry

\section{EXAMPLE CLAIMS OF A GRANTED AUSTRALIAN PATENT DIRECTED TO VARIOUS GENETIC MATERIAL}

We have randomly selected a patent granted in Australia some time ago to provide an example of the types of claims to genetic material that have previously been granted by the APO. This patent $^{27}$ describes nucleotide sequences for MAGE-C1 and MAGE-C2, which are melanoma antigen family $\mathrm{C}$ family member proteins that are expressed in testis (and sometimes placenta), but not in other normal tissue, and are reactivated in various tumors. Because of the expression of these proteins on tumor cells, they are described in the patent as attractive targets for tumor immunotherapy.

The first seven claims that were granted are presented below. ${ }^{28}$ As these claims were granted, they were considered by the Australian examiner to constitute patentable subject matter. A review of the claims provides an insight into what types of claims directed to genetic material the APO has allowed.

1. An isolated nucleic acid molecule which encodes a TRAP having an amino acid sequence of $a$ TRAP encoded by a nucleotide sequence selected from the group consisting of SEQ ID NO: 9 and SEQ ID NO: 18 .

SEQ ID Nos. 9 and 18 refer to nucleotide sequences of a cDNA of MAGE-C1 and MAGEC2, respectively. Claim 1 could be broadly read to include, for example, an isolated chromosome Xq26-q27 that contains the native MAGE-C2 sequence.

2. An isolated nucleic acid molecule having a nucleotide sequence which encodes a tumor rejection antigen precursor, said isolated nucleic acid molecule comprising a nucleotide sequence set forth in SEQ ID NO: 9 or SEQ ID NO: 18.

3. The isolated nucleic acid molecule of claim 1, wherein said nucleic acid molecule is a cDNA molecule.

\footnotetext{
${ }^{27}$ Australian Patent No. 739680.

${ }^{28}$ Our comments in relation to these claims are illustrative only and are not determinative of any claim interpretation, scope, or validity.
}

Claim 3 states that the isolated nucleic acid is a cDNA that is DNA synthesized from a messenger RNA (mRNA).

4. The isolated nucleic acid molecule of claim 1, wherein said nucleic acid molecule is a gDNA molecule.

Claim 4 states that the isolated nucleic acid molecule is genomic DNA. As claim 4 is dependent on claim 1 , it reinforces the possible construction that claim 1 includes a chromosome or fragment of a chromosome.

5. An isolated nucleic acid molecule, the complementary sequence of which hybridizes under stringent conditions to a nucleic acid molecule having a nucleotide sequence which consists of nucleotides 1-2815 of SEQ ID NO: 9 with the proviso that the complementary sequence does not hybridize to SEQ ID NO: 8 under stringent conditions.

6. An isolated mRNA molecule, which is complementary to the nucleic acid molecule of claim 1.

Claim 6 defines an isolated mRNA molecule that defines mature mRNA but could arguably also relate to pre-mRNA.

7. An expression vector comprising the isolated nucleic acid molecule according to claim 1 operatively linked to a promoter.

Finally, claim 7 defines a vector including an isolated nucleic acid of claim 1 arranged to a promoter that allows expression.

This patent was filed in 1998. For the reasons outlined above, given the change in law and underlying science, it is unlikely that a patent would be granted with claims of this language if it was filed today. However, this patent clearly highlights that Australia has been a fertile ground for patenting various types of genetic material.

\section{CONCLUSION}

Patents that claim genetic material have regularly been granted in Australia. It is likely that this will continue unless there is legislative change that excludes genetic material from patentable subject matter.

Australian courts are unlikely to hold that genetic material is not patentable subject matter in circumstances in which the government has 
chosen not to amend the legislation. As an example of this perceived reluctance, in a recent decision that was issued on December 4, 2013, Australia's highest court confirmed that methods of medical treatment are patentable subject matter (Apotex Pty Ltd v. Sanofi-Aventis Austra- lia Pty Ltd (2013) (HCA 50)). The court was reluctant to find that methods of medical treatment were not patentable when the government looked closely at this issue and decided not to exclude methods of medical treatment from patentable subject matter. 


\section{$\&_{\mathrm{CSH}}^{\infty} \&$ Cold Spring Harbor

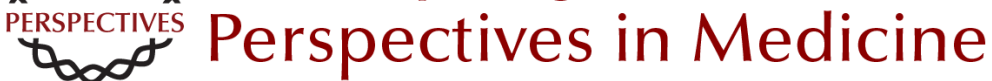

\section{Decoding Gene Patents in Australia}

Adam Denley and James Cherry

Cold Spring Harb Perspect Med 2015; doi: 10.1101/cshperspect.a020909 originally published online October 3, 2014

\section{Subject Collection Intellectual Property in Molecular Medicine}

Patentability of Stem Cells in the United States Sarah E. Fendrick and Donald L. Zuhn, Jr.

Inventorship and Authorship Antoinette F. Konski and Linda X. Wu

The Patentability of Stem Cells in Australia Jenny Petering and Prue Cowin

Impact of America Invents Act on Biotech Intellectual Property

Amanda Murphy, Michael Stramiello, Jonathan Stroud, et al.

Introduction to Intellectual Property: A U.S.

Perspective

Amanda Murphy, Michael Stramiello, Stacy Lewis, et al.

The Role of Regulatory Agencies and Intellectual Property: Part I

Kevin E. Noonan

Canada's Patented Medicines (Notice of Compliance) Proceedings and Intellectual

Property

Henry Bian and Conor McCourt

Patentability of Genes: A European Union

Perspective

Paul Cole
The Impact of Myriad on the Future Development and Commercialization of DNA-Based Therapies and Diagnostics

Michele Wales and Eddie Cartier

Protecting Traditional Knowledge Related to

Biological Resources: Is Scientific Research

Going to Become More Bureaucratized?

Prashant Reddy and Malathi Lakshmikumaran

Protecting Trade Secrets in Canada

Noel Courage and Janice Calzavara

Inherent Anticipation in the Pharmaceutical and

Biotechnology Industries

Michael Goldman, Georgia Evans and Andrew Zappia

The Role of Regulatory Agencies and Intellectual

Property: Part II

Kevin E. Noonan

Baseball Bats and Chocolate Chip Cookies: The Judicial Treatment of DNA in the Myriad Genetics Litigation lan Binnie and Vanessa Park-Thompson

The Impact of Myriad and Mayo: Will

Advancements in the Biological Sciences $\mathrm{Be}$

Spurred or Disincentivized? (Or Was Biotech

Patenting Not Complicated Enough?) Jennifer Gordon

Trade Secrets in Life Science and Pharmaceutical Companies

Tara Nealey, Ronald M. Daignault and Yu Cai

For additional articles in this collection, see http://perspectivesinmedicine.cshlp.org/cgi/collection/ 